\title{
РОТАЦІЙНЕ ОБРІЗУВАННЯ АРКУШЕВОГО МАТЕРІАЛУ У ВКЛАДАЛЬНО-ШВЕЙНО-РІЗАЛЬНИХ АГРЕГАТАХ
}

๔ А.І. Іванко, К.Т.н, доцент, С.О. Семеняга, НТУУ “КПІ”, Київ, Україна

\author{
В статье рассмотрена новая конструкция устройства \\ безвыстойной ротационной обрезки листового материала \\ во вкладочно-швейно-резательных агрегатах.
}

In the article is described the new construction of device of the continual rotary trimming of sheet material in inserting-sewing-cuttings aggregates.

\section{Постановка проблеми}

Технологічні процеси обрізування книжкових, журнальних та брошурних блоків, підготовка їх корінцевої частини до незшивного клейового скріплення вимагають від спеціалізованого поліграфічного устаткування постійно збільшувати продуктивність роботи та одночасно зменшувати масогабаритні параметри.

Вкладально-швейно-різальні агрегати (ВШРА) складаються із секцій транспортування і синхронізації, обрізування та виведення готових виробів [1]. Брошури транспортером подаються в різальну секцію. Їх обрізування плоскими ножами відбувається у двох позиціях. У першій брошури обрізуються ножем 3 переднього краю, а потім пасовими транспортерами подаються в другу позицію, де відбувається обрізування двома ножами головки та хвостика. Передній ніж в першій позиції та бокові ножі в другій позиції працюють синхронно.
Після базування брошури опускаються ніж і закріплений на ножотримачі підпружинений механізм притискача з башмаком. Брошури вивідним стрічковим транспортером подаються на приймальний транспортер.

Виконання операцій базування брошур і їх обрізування 3 трьох боків супроводжуються роботою верхнього та нижнього пасових транспортерів та додатково ланцюгового транспортера з упорами.

Недоліками даного технологічного процесу є вистійний спосіб обрізування брошур. А циклічність переднього та двох бокових ножів створюють значні інерційні навантаження.

Фрезерно-торшонувальна секція, яка може входити в блокообробну лінію характеризується значними енергозатратами через необхідність використання потужних фрезерного і торшонувального приводів; значна трудомісткість обслуговування пристрою під час заміни та переналагодження різців фрези 
та інтенсивне виділення паперового пилу.

\section{Аналіз попередніх досліджень}

Відомий спосіб і пристрій для обрізування друкованої продукції [2], який містить два перпендикулярно розташовані обертові барабани з вмонтованими у них комірками. Барабани 3 комірками отримують обертовий рух відносно своїх центральних осей. Комірки почергово розміщені на основі барабана і відокремленні одна від одної спицями із закріпленими на них контрножами. Кожна комірка з нерухомими контрножами по обидва торцеві боки барабана обмежується двома дисковими ножами.

Таким чином відбувається обрізування головки і хвостика друкованої продукції. Для обрізування передка використовується другий барабан з одним дисковим ножам.

Недоліками пристрою є:

- складність переналагодження на інший формат продукції. Складність полягає у тому, що ножі, які закріплені на спицях окремо переставляються по осі барабана, а при необхідності потрібно проводити заміну контрножів на більш широкі або більш вузькі. Заміна потребує великих фізичних і часових затрат;

- велика кількість комірок призводить до обмеження товщини аркушевої продукції, що обрізується;

- виключена можливість підготовки корінця друкованої продукції до нанесення клею.

\section{Мета роботи}

Метою даної роботи поставлена задача підвищення товщини обрізування та якості підготовки корінця аркушевої продукції до незшивного клейового скріплення при спрощенні пристрою, зниженні потужності споживання приводу, збільшенні продуктивності роботи пристрою шляхом конструктивних змін існуючого устаткування. А також за рахунок зменшення сумарної сили різання та одночасного виконання додаткової операції торшонування корінця спроектувати принципово нове високопродуктивне обладнання.

\section{Результати проведених досліджень}

Поставлена задача вирішується тим, що у пристрої для ротаційного обрізування аркушевої продукції та підготовки її до нанесення клею, що містить два обертових барабани 3 інструментальними вузлами та приводом для його переміщення, інструментальний вузол першого барабана містить чотири каретки та кулачковий механізм, а інструментальний вузол другого барабана містить чотири пари ножів, причому усі ножі виконані криволінійним, а в двох парах ножів вмонтовані торшонуючі різці.

Дві з чотирьох пар ножів почергово можуть обрізувати головку і хвостик аркушевої продукції, а дві інші - передок і корінець. А стінка каретки механізму захоплювачів для регулювання притиску аркушевої продукції виконана підпружиненою. 
Використання двох барабанів із зустрічним рухом затиснутої в каретках продукції в одному та обертовими назустріч ножами в іншому дозволяє здійснити послідовно-поступове зрізання площин друкованої продукції та надає дуговим ножам відповідну траєкторію руху, яка сприяє зменшенню сумарної сили різання: вертикальної, горизонтальної та лобової і, таким чином, зниженню необхідної потужності споживання приводу. Торшонуючі ножі дозволяють одночасно із зрізуванням наносити мікрорельєф на поверхню корінця для більш якісного закріплення на ньому клею, що підвищує міцність клейового скріплення, зменшує кількість необхідних операцій з підготовки корінця та збільшує продуктивність роботи пристрою.

Спосіб безупинного ротаційного обрізування сфальцьованого аркушевого матеріалу, підготовки корінця до нанесення клею та пристрій для його реалізації зображено на рис. 1 .

Пристрій складається 3 двох барабанів: на барабані 4 каретки 8, із зафіксованими у них сфальцьованим аркушевим матеріалом 13; інструментальний вузол для обрізування головки, хвостика, передка та підготовки корінця матеріалу на барабані 5; привод для переміщення барабанів. Привод переміщення барабанів включає в себе двигун 1 та чотири зубчасті колеса 3.

Чотири механізми кареток 8 барабана 4 обертаються разом з аркушевим матеріалом 13 навколо центральної його осі $\mathrm{O}_{1}$. Захоплення аркушевого мате- ріалу та його затискування механізмом каретки відбувається за рахунок кулачкового привода. Кулачковий привод кареток 8 складається з двох кулачків 11 нерухомо закріплених на осі $\mathrm{O}_{1}$ по обидва боки барабана 4 та чотирьох пар роликів 10. Кожен ролик пари кулачкового механізму обкочує заданий профіль кулачка 11 за рахунок пружин розтягу 12 , що шарнірно з'єднані 3 центром обертання барабана $\mathrm{O}_{1}$. Ланка затиску каретки 2 жорстко кріпиться до важеля 9 і обертається разом з ним по радіусу $\mathrm{O}_{1} \mathrm{O}_{4}$. Положення ланки затиску 2 визначається положенням важеля 9 за рахунок траєкторії ролика 10 з центром осі обертання $\mathrm{O}_{3}$. Виконавчі механізми барабана 4 приводяться в рух за рахунок вала 4.

Інструментальний вузол барабана 5 для почергового обрізування головки, хвостика, передка та одночасної підготовки корінця сфальцьованого аркушевого матеріалу 13 до нанесення клею вміщує в собі чотири пари ножотримачів 17, дугоподібних 18 та торшонувальних 19 ножів. Ножотримачі 17 разом із різальними інструментами приводяться в рух від шестерні 3 і обертаються за рахунок вала 16.

В ножах 19 вмонтовані торшонуючі різці 20. Усі дугоподібні ножі 18 окрім торшонувальних 19 виготовлені однакової форми. Аркушевий матеріал з площиною обробки В обрізується ножами довжиною L з урахуванням величини перекриття.

Пристрій працює наступним чином (див. рис. 1). При потраплянні аркушевого матеріалу в 

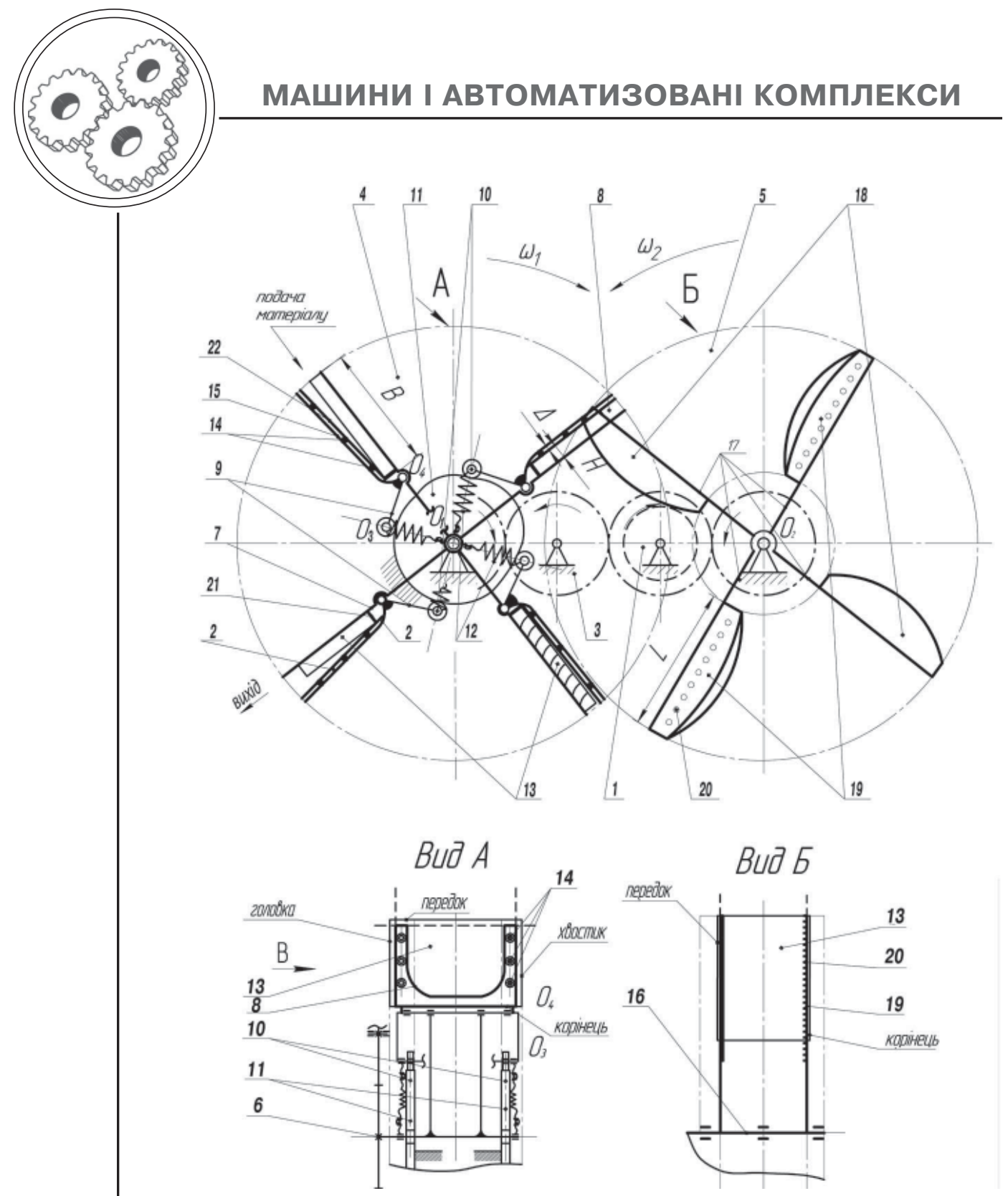

Рис. 1. Спосіб безупинного ротаційного обрізування сфальцьованого аркушевого матеріалу, підготовки корінця до нанесення клею та пристрій для його реалізації

зону каретки відбувається його вирівнювання упорами 21 та фіксування ланкою затиску 2. Аркушевий матеріал почергово потрапляє в каретку до розташованих вирівнювальних упорів 21 двома варіантами: перший - корінцем, або передком вперед та другий - головкою, або хвостиком вперед.

Сфальцьований аркушевий матеріал 13 заданою масою $\mathrm{m}_{\mathrm{a}}$ завширшки $H$ подається для безупинного ротаційного обрізування його головки і хвостика за один захід, передка і підго- 
товки корінцевої частини до нанесення клею за другий захід в затиснутому стані кареткою 8 обертового барабана 4.

Спільний двигун 1 та зубчасті колеса 3 забезпечують обертання барабанів 4 та 5 один на зустріч іншому.

Дві пари ножів з чотирьох, і кожна з яких складається з дугоподібного 18 та торшонуючого 19 ножів за один захід обрізують передок сфальцьованого аркушевого матеріалу та торшонують його корінець. Дві інші пари, кожна з якої складається з двох однакових дугоподібних ножів і розташованих паралельно обрізує головку і хвостик.

Приводяться в зустрічний рух барабани 4 та 5 пристрою з умовою $\omega_{1}=\omega_{2}$ за рахунок зубчастих коліс 3 від двигуна 1.

Ланка затиску каретки відображена на рис. 2. Вона конструктивно виконана з двох стінок: робочої 22, що контактує з аркушевим матеріалом та допоміжної 15, яка надає необхідне зусилля затиску. Між робочою та допоміжною стінками встановлені пружини стиску 14 з можливим регулюванням на розмір $\Delta$ в залежності від товщини матеріалу $H$. Функцію контрножа безмарзанного способу різання виконує накладний стіл каретки 7.

Маса стосу аркушів, що буде оброблятися визначається за формулою: $\mathrm{m}_{\mathrm{a}}=(\mathrm{L} \cdot \mathrm{A} \cdot \mathrm{H} \cdot \mathrm{c}) \cdot 10^{3}$, де L, A, H - довжина, ширина i висота аркушевого матеріалу; с - густина паперу. Відповідно виникаюче напруження стиску в аркушевому матеріалі під час затиску кареткою становитиме:

$$
\sigma=\frac{F_{п р}}{\gamma \cdot B \cdot L},
$$

де $F_{\text {пр }}=(0,8 \ldots 1,3) \cdot F_{\text {різ }}-$ зусилля затиску аркушів, що залежить від максимального зусилля різання ( $\alpha-$ фізико-механічних характеристик паперу); $\gamma$ - коефіцієнт, що враховує конфігурацію робочої площини ланки затиску; В - ширина ланки затиску каретки; L - геометричний розмір аркушевого матеріалу.

\section{Buव B}

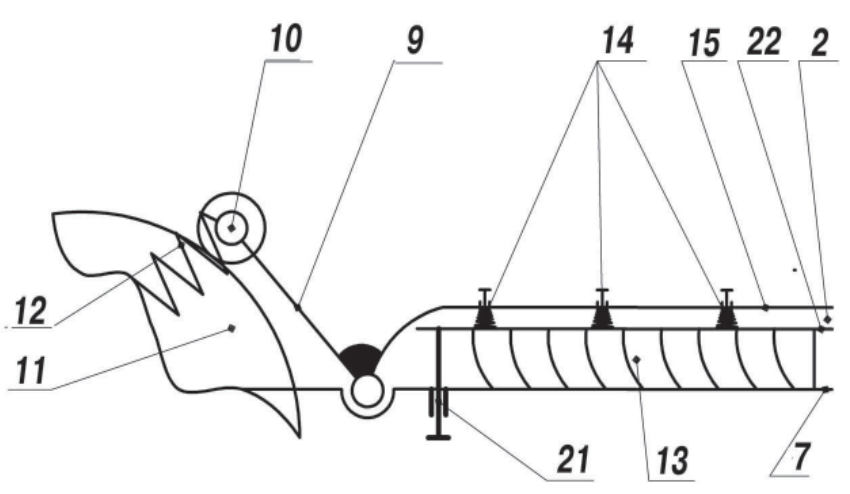

Рис. 2. Ланка затиску каретки 
Середня потужність, що витрачається на деформацію аркушів за цикл:

$$
N_{в}=\frac{A_{\text {м.к. }}}{t_{д} \cdot \eta_{\text {М.к. }}},
$$

де $A_{\text {м.к. }}$ - робота, що затрачається механізмом каретки; $t_{d}$ - тривалість періоду деформації аркушів кареткою; $\eta_{\text {м.к. }}$ - к.к.д. механізму каретки.

Для варіанту інструментального вузла, пара якої працює з торшонуючим ножем за цикл одночасно обрізується передок аркушевого матеріалу, а на його корінці залишається різноспрямований дугоподібний мікрорельєф, який сприяє більш міцному клейовому з'єднанню. Рельєф може бути нанесено згідно рекомендацій 3 інтервалом 2-20 мм, кутом заглиблення $40^{\circ}-70^{\circ}$ та глибиною заглиблення 0,8-1,5 мм.

\section{Висновки}

Використання способу безупинного ротаційного обрізування сфальцьованого аркушевого матеріалу, підготовки корінця до нанесення клею та пристрою для його реалізації, дозволить збільшити товщину сфальцьованого аркушевого матеріалу, що обробляється; скоротити час на переналагодження і заміну дугових ножів; спростити конструкцію пристрою; забезпечити міцність клейового скріплення; зменшити габарити пристрою.

Дана конструкція механізму після проведення експериментальних досліджень може бути рекомендована до впроваджена у серійне виробництво, як окрема секція ВШРА.

1. Хведчин Ю. Й. Брошурувально-палітурне устаткування. Ч. І. Брошурувальне устаткування. Підручник. - Львів : ТеРус, 1999. - 336 с. 2. Пат 5113731A United States Patent, MKE B 26 D 1/22, B 26 D 9/00. Method and apparatus for cutting printed products / Reist Walter; Ferag AG. № US19910790026 19911106; заявл. 06.11.1991; опубл. 19.05.1992, Appl. №. : 790,026. - 14 с. 3. Топольницький П. В. Нові технології та пристрої для різання поліграфічних матеріалів та книжково-журнальних блоків: навч. посіб. / Топольницький П. В., Книш О. Б. - Львів : Афіша, 2003. - 88 с. 4. Іванко А. І. Механіка процесу обрізування книжково-журнальних блоків дисковими ножами 3 планетарним приводом : дис. ... канд. техн. наук: 05.05.01 / А. І. Іванко - Київ, 2007. - 181 с. 5. Пат. України на винахід № 90543. B26D 1/01. Спосіб обрізування брошур із трьох сторін і пристрій для його реалізації / Полюдов О. М., Регей І. І., Книш О. Б., Кравець В. Ю.Заявл. 22.04.2008; Опубл. 11.05.2010. - Бюл. № 9, 2010. - 2 с. 6. Пат. України на винахід № 94535. B42C 5/00, B26D 1/153, B26D 3/00, B42C 13/00. Спосіб підготовки корінця книжкового блока до нанесення клею і пристрій для його реалізації / Полюдов О. М., Регей І. І., Книш О. Б., Коломієць А. Б.Заявл. 20.04.2010; Опубл. 10.05.2011. - Бюл. № 9, 2011. - 3 с.

$$
\begin{array}{r}
\text { Рецензент - В. Г. Яницький, к.т.н., } \\
\text { доцент, НТУУ «КПІ» }
\end{array}
$$

